\title{
Taxonomic study of three new Antarctic Asterochloris (Trebouxio- phyceae) based on morphological and molecular data
}

\author{
Jong Im Kim ${ }^{1}$, Yong Jun Kim ${ }^{1}$, Seung Won $\mathrm{Nam}^{2}$, Jae Eun So ${ }^{3}$, Soon Gyu Hong ${ }^{3}$, Han-Gu \\ $\mathrm{Choi}^{3}$ and Woongghi Shin ${ }^{1, *}$
}

${ }^{1}$ Department of Biology, Chungnam National University, Daejeon 34134, Korea

${ }^{2}$ Nakdonggang National Institute of Biological Resources, Sangju 37242, Korea

${ }^{3}$ Division of Polar Life Sciences, Korea Polar Research Institute, Incheon 21990, Korea

Asterochloris is one of the most common genera of lichen phycobionts in Trebouxiophyceae. Asterochloris phycobionts associated with the lichenized fungi Cladonia and Stereocaulon in King George Island (Antarctica) and Morro Chico (Chile), were isolated and then used to establish clonal cultures. To understand the phylogenetic relationships and species diversity of Antarctic Asterochloris species, molecular and morphological data were analyzed by using three microscopy techniques (light, confocal laser and transmission electron) and a multi-locus phylogeny with data from the nuclear-encoded internal transcribed spacer (ITS) rDNA and the actin and plastid-encoded ribulose bisphosphate carboxylase large chain $(r b c \mathrm{~L})$ coding genes. Morphological data of three Antarctic strains showed significant speciesspecific features in chloroplast while molecular data segregated the taxa into distinct three clades as well. Each species had unique molecular signatures that could be found in secondary structures of the ITS1 and ITS2. The species diversity of Antarctic Asterochloris was represented by six taxa, namely, A. glomerata, A. italiana, A. sejongensis, and three new species (A. antarctica, A. pseudoirregularis, A. stereocaulonicola).

Key Words: Antarctica; Asterochloris; lichen; photobiont; phylogeny; taxonomy; Trebouxiophyceae

\section{INTRODUCTION}

Lichens are among the best-known examples of symbiotic organisms and consist of fungal partners (mycobionts) and photosynthetic eukaryotic algal (phycobionts) or cyanobacterial (cyanobionts) partners. Lichens are biologically and ecologically important in terrestrial environments due to their influence on global carbon and nitrogen circulation, playing an essential role during early ecological succession (Fernández-Mendoza et al. 2011, Elbert et al. 2012, Pérez-Ortega et al. 2012, Borchhardt et al. 2017). Within lichen associations, the lichen-forming phycobionts transfer carbohydrates to the heterotrophic host in the form of sugar alcohol or glucose (Richardson et al. 1967, Richardson and Smith 1968), while mycobionts protect their partners from solar radiation and harsh environmental conditions such as extreme temperature fluctuations and desiccation (Honegger 2012). These partners have species selectivity, meaning that they correspond to each other, but not always in a one-to-one manner (Chodat 1913, Jaag 1929, Raths 1938, Kroken and Taylor 2000, Piercey-Normore and DePriest 2001, Muggia et al. 2018). To date, approximately 19,400 species of lichens have been described,
(9) $\$$ This is an Open Access article distributed under the terms of the Creative Commons Attribution Non-Commercial License (http://creativecommons.org/licenses/by-nc/3.0/) which permits unrestricted non-commercial use, distribution, and reproduction in any medium, provided the original work is properly cited.
Received November 7, 2019, Accepted February 23, 2020

*Corresponding Author

E-mail: shinw@cnu.ac.kr

Tel: +82-42-821-6409, Fax: +82-42-822-9690 
distributed in diverse climates from tropical to polar regions (Kirk et al. 2008, Garrido-Benavent and Pérez-Ortega 2017). Many studies of lichen taxonomy have focused on the mycobiont, but relatively less attention has been paid proportionally to the lichen-forming phycobiont. Although approximately 40 genera and 100 species of photobionts are known globally (Tschermak-Woess 1988, Friedl and Büdel 2008, Muggia et al. 2018), taxonomic studies of eukaryotic algae acting as phycobionts are not sufficient to understand their species diversity, especially in the Antarctic region (Engelen et al. 2016, Garrido-Benavent et al. 2017, Beck et al. 2019).

Asterochloris is closely related to the genus Trebouxia in having similar morphological characters of vegetative cells. In 1867, Schwendener recognized that a lichen is an association of green bodies and fungal hyphae. Subsequently, Treboux (1912) included the green bodies as members of the formerly described genus Cystococcus, following the classification system of Nägeli (1849). Warén (1920) made an attempt to divide Cystococcus into two subgenera (Eucystococcus and Eleuterococcus) based primarily on the number of autospores and added eight new species to the two subgenera. Later, Puymaly (1924) recognized that Cystococcus humicola, the type species described by Nägeli (1849), was a different species from the lichen-forming green coccoid alga and suggested a new genus name, Trebouxia, based on observations of the gonidia in the thallus of the lichen species Xanthoria parietina. Thereafter, Ahmadjian $(1960,1967)$ classified Trebouxia into two groups using chloroplast features and vegetative cell shape. In addition, Archibald (1975) established a new genus, Pseudotrebouxia, based on differences in cell-wall characters during asexual reproduction. However, morphological and molecular data did not support Archibald's classification system (Gärtner 1985, Friedl and Zeltner 1994, Friedl and Rokitta 1997). In 1980, Tschermak-Woess established a new genus, Asterochloris, for microalgae devoid of autospores.

Recently, many molecular studies have supported Trebouxia and Asterochloris as distinct monophyletic clades. Early molecular studies performed based on nuclear small subunit and large subunit (LSU) rDNA sequence data suggested that Trebouxia magna and $T$. erici were more closely related to Myrmecia biatorellae than other members of Trebouxia s. str. (Friedl and Zeltner 1994, Friedl 1995, Friedl and Rokitta 1997). PierceyNormore and DePriest (2001) showed the monophyly of Asterochloris using nuclear internal transcribed spacer (ITS) 1, $5.8 \mathrm{~S}$ and ITS2 sequence data. Later, an 18S rDNAbased phylogenetic tree of lichen photobionts revealed that Asterochloris was a monophyletic genus distinct from the closely related genera Myrmecia and Trebouxia (Friedl and Büdel 2008). Škaloud and Peksa (2010) emended the diagnosis of the genus Asterochloris and revealed 16 lineages in the genus, including nine new species-level lineages (Škaloud et al. 2015). More recently, eight new species of Asterochloris have been reported based on chloroplast morphology and molecular data (Moya et al. 2015, Škaloud et al. 2015, Kim et al. 2017).

To understand the phylogenetic relationships and taxonomy of Asterochloris isolated from lichen thalli in the vicinity of King Sejong Station, King George Island (Antarctica) and Morro Chico (Chile), the morphological characters of lichen phycobionts were investigated by using light microscopy (LM), confocal laser microscopy (CM), and transmission electron microscopy (TEM). Molecular data analyses were also performed based on three genetic markers (nuclear-encoded internal transcribed spacer [ITS]), actin, and plastid-encoded ribulose bisphosphate carboxylase large chain $(r b c \mathrm{~L})$ to understand the phylogenetic relationships among the newly isolated Asterochloris and known members of this genus.

\section{MATERIALS AND METHODS}

\section{Taxon sampling}

Specimens of Cladonia sp., Cladonia gracilis, Sphaerophorus globosus, and Stereocaulon sp. were collected from nine different locations in Morro Chico (-52.032838 S / -71.250226 W), Chile, and on King George Island, Antarctica, in February 2015 (1st, -62.131490 S / -58.459550 W; 2nd, -62.13123 S / -58.458890 W; 3rd, -62.129730 S / -58.456110 W; 4th, $-62.135100 \mathrm{~S} /-58.467100 \mathrm{~W}$; 5th, $-62.133670 \mathrm{~S} /-58.470210 \mathrm{~W}$; 6th, $-62.132420 \mathrm{~S} /$ $-58.462120 \mathrm{~W}$; 7th, $-62.131230 \mathrm{~S} /-58.458890 \mathrm{~W}$ ) and in February 2016 (1st, -62.132280 S / -58.464390 W; 2nd, $-62.132190 \mathrm{~S} /$-58.464420 W). Lichen species were identified by morphological characteristics and chemical substances according to species descriptions (Øvstedal and Smith 2001, Olech 2004). Chemical analyses were performed by standard methods (Culberson 1972, Orange et al. 2001).

\section{Phycobiont isolation and cultivation}

Initially, a small piece of rehydrated lichen thallus was fragmented by chopping with a sharp razor in a Petri dish or macerated by using a glass slide. Each free-laying 
algal cell surrounded by broken pieces of the fungal hyphae was isolated by a micropipette. Then, each cell was washed five times with 3N Bold's Basal medium (3NBBM) modified according to Thomas and Montes (1978) and transferred into the same medium in a well of a 96-well plate. The cells within the plate were incubated at $17^{\circ} \mathrm{C}$ under a $14: 10 \mathrm{~h}$ light : dark cycle with $30 \mu \mathrm{mol}$ photons $\mathrm{m}^{-2} \mathrm{~s}^{-1}$ using cool white fluorescent bulbs.

\section{Light microscopy}

Each culture strain was observed and identified under an Axio Imager.A2 (Carl Zeiss Inc., Hallbergmoos, Germany) equipped with differential interference contrast optics. Cell images were obtained with an AxioCam HRc (Carl Zeiss Inc.) photomicrographic system. Numerical values of morphological characters were determined by measuring 25-30 cells of each taxon from photographic images. We followed the terminology from Škaloud et al. (2015) and Gärtner (1985) for descriptions of detailed chloroplast morphology.

\section{Confocal microscopy}

CM was conducted with an LSM5 laser scanning confocal microscope equipped with an argon-krypton laser (Carl Zeiss Inc.). A $488 \mathrm{~nm}$ excitation line and an AOBS filter-free system were employed to collect emitted light between 498 and $700 \mathrm{~nm}$. The autofluorescence of chlorophyll was used to visualize chloroplast structure. Collections of optical sections through chloroplasts were used to obtain a three-dimensional reconstruction of chloroplast morphology. The reconstructions of chloroplasts were made by LSM 5 software version 3.5 (Carl Zeiss Inc.).

\section{Transmission electron microscopy}

For TEM, aliquots of the culture were pelleted by centrifugation for $2 \mathrm{~min}$ at 2,300 $\times \mathrm{g}(5,000 \mathrm{rpm})$ in an Eppendorf 5415D centrifuge (Eppendorf, Hamburg, Germany). After removing the supernatant, the pelleted cells were fixed in $2.5 \%$ glutaraldehyde mixed with 3NBBM culture medium for $1 \mathrm{~h}$ at $4^{\circ} \mathrm{C}$. The glutaraldehyde-fixed cell pellets were washed 3 times in 3 NBBM culture medium and postfixed in $1 \% \mathrm{OsO}_{4}$ for $1 \mathrm{~h}$ at $4^{\circ} \mathrm{C}$. Dehydration, embedding, and polymerization were performed following the methods of Kim et al. (2017). The polymerized blocks were thinly sectioned to a thickness of $70 \mathrm{~nm}$. Sections were collected on formvar-coated slot copper grids, stained with 3\% uranyl acetate and Reynold's lead citrate (Reynolds 1963) and examined and photographed with a JEM-1010 transmission electron microscope operating at $80 \mathrm{kV}$ (JEOL, Tokyo, Japan). Images of the sections were recorded on Kodak EM Film 4489 (Eastman Kodak Co., Rochester, NY, USA) and scanned in tagged image file (TIF) format using Epson Perfection V700 Photo (Epson Korea Co., Ltd., Seoul, Korea).

\section{DNA isolation, amplification, and sequencing}

Cultured cells were harvested by centrifugation at the exponential growth phase (Eppendorf 5415D). Genomic DNA was extracted from the culture strains with a DokDo-Prep Genomic DNA Kit (Elpis-Biotech Inc., Daejeon, Korea), employing the animal tissue protocol described by the manufacturer. The nuclear ITS rDNA, actin and plastid $r b c \mathrm{~L}$ coding gene were amplified by using a combination of forward and reverse primers in a T100 thermal cycler (Bio-Rad, Hercules, CA, USA). Amplification of the internal ITS rDNA, actin, and $r b c \mathrm{~L}$ coding gene was performed with the following primers: ITS5F (5'-GGA AGT AAA AGT CGT AAC AAG G-3') (White et al. 1990), ITS4R (5'-TCC TCC GCT TAT TGA TAT GC-3') (White et al. 1990), actinF2 (5'-AGC GCG GGT ACA GCT TCA C-3') (Kim et al. 2017), actinR2 (5'-CAG CAC TTC AGG GCA GCG GAA3') (Škaloud and Peksa 2010), PRASF5 (5'-ATG GTT CCA CAA ACA GAA AC-3') (Škaloud et al. 2015), PRASR5R (5'TTG TCA ATA GTA TCA AAT TC-3') (Sherwood et al. 2000, Škaloud et al. 2015), Astero_rbcLF (5'-GGC TTT AAA GCA GGT GTA AAA G-3') (this study), and Astero_rbcLR (5'CAC GAC CSG CGT TTC GKG-3') (this study). The three genes were amplified by using a $25 \mu \mathrm{L}$ reaction mixture containing $2 \mu \mathrm{L}$ of DNA ( $20 \mathrm{ng}$ ), $1.0 \mu \mathrm{L}$ of each primer (10 pmol), $1 \mu \mathrm{L}$ of Accupower PCR PreMix (Bioneer Corporation, Daejeon, Korea) and enough distilled water to reach a total reaction volume of $25 \mu \mathrm{L}$. The DNA amplifications were performed using the following program: $5 \mathrm{~min}$ of denaturation at $94-95^{\circ} \mathrm{C} ; 35-40$ cycles of $94-95^{\circ} \mathrm{C}$ for 30 s, $45-55^{\circ} \mathrm{C}$ for $1 \mathrm{~min}$, and $72^{\circ} \mathrm{C}$ for $1-2 \mathrm{~min}$; a final extension at $72^{\circ} \mathrm{C}$ for $7-10 \mathrm{~min}$; and an infinite hold at $4^{\circ} \mathrm{C}$. The polymerase chain reaction (PCR) products were loaded onto an agarose gel and purified using a LaboPass PCR purification kit and LaboPass gel extraction kit (Cosmo Genetech Corporation, Daejeon, Korea) according to the manufacturer's protocols. The purified PCR products were sequenced by using the PCR primers at Macrogen Corp. (Seoul, Korea). Forty-six new sequences were generated: 14 sequences of the nuclear ITS1, 5.8S, and ITS2 rDNA regions; 14 sequences of the actin gene and 18 se- 

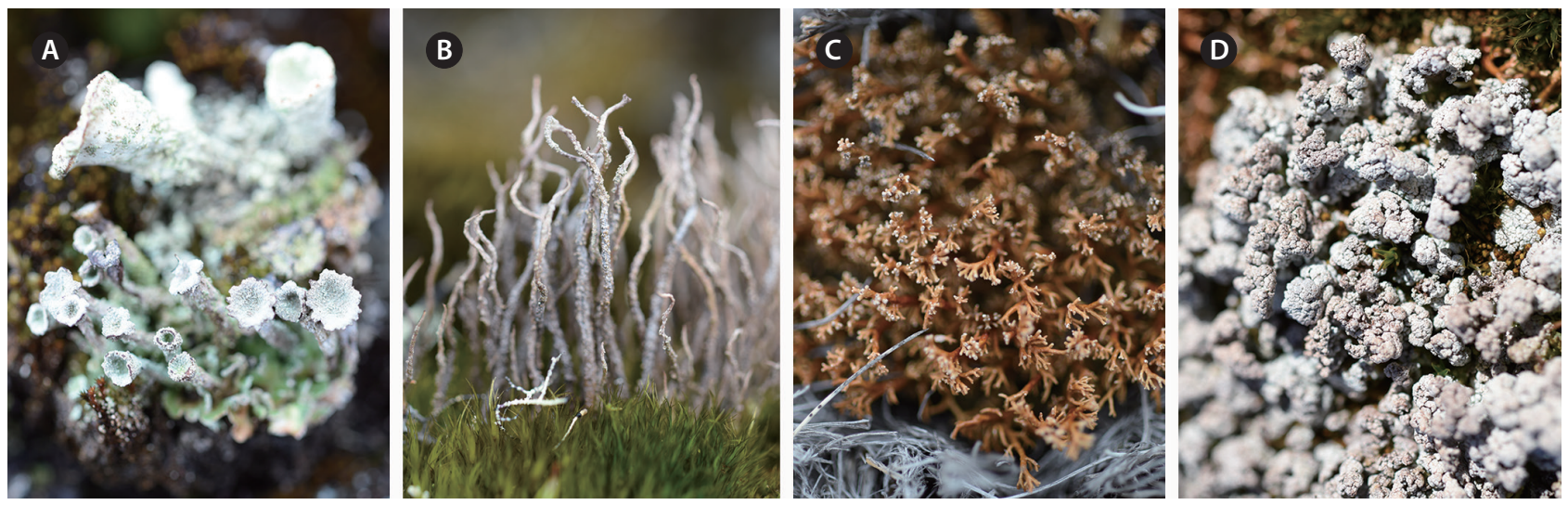

Fig. 1. Habitus of lichens from which the new species of Asterochloris were discovered. (A) Cladonia sp. showing primary squamules and cupshaped podetia covered with powdery soredia. (B) Cladonia gracilis showing brown-colored, slender and unbranched podetia. (C) Sphaerophorus globosus showing yellowish-brown color and dichotomous branching. (D) Stereocaulon sp. showing a pale gray and granular thallus.

quences of the $r b c \mathrm{~L}$ gene. These sequences were aligned by eye using the Genetic Data Environment (GDE 2.6) program (Smith et al. 1994). The conserved regions of the three loci sequences were aligned across taxa and used for phylogenetic analyses. We excluded the parts of the sequences that could not be aligned.

\section{Phylogenetic analyses}

The combined dataset consisted of previously published and newly generated sequences. The dataset included 110 ITS rDNA, 102 actin gene and $24 \mathrm{rbcL}$ gene sequences from Asterochloris (Supplementary Table S1). The dataset consisted of 2,252 characters (nuclear ITS = 506 , actin $=426, r b c \mathrm{~L}=1,320$ ) for phylogenetic analysis. Maximum likelihood (ML) analyses were performed by using RAxML version 8.2.12 (Stamatakis 2014) with a single general time-reversible plus gamma (GTR + GAMMA) model. We performed 1,000 tree inferences by using the -\# option of the program to identify the best tree. Bootstrap values (ML bootstrap support) were computed based on 1,000 pseudoreplicates with the same substitution model. Bayesian analyses were implemented using MrBayes 3.2.6 (Ronquist et al. 2012), with the starting tree constructed randomly, two simultaneous runs (nruns = 2) and four Metropolis-coupled Markov chain Monte Carlo $\left(\mathrm{MC}^{3}\right)$ algorithms for $10 \times 10^{6}$ generations, with one tree maintained every 1,000 generations. Burn-in point was identified graphically by tracking the likelihoods (Tracer v.1.6; http://tree.bio.ed.ac.uk/software/tracer/). The first 2,500 trees were discarded, and the remaining 7,501 trees were used to calculate the posterior probabili- ties (PP) of each clade. Additionally, the sump command in MrBayes was used to confirm convergence. This analysis was repeated twice independently, with both analyses resulting in the same tree. The trees were visualized using the FigTree v.1.4.4 program, available at http://tree.bio. ed.ac.uk/software/figtree/.

\section{Phycobiont ITS secondary structure}

Secondary structures of the nuclear ITS sequences were built using the Mfold v.2.3 program (Walter et al. 1994, Zuker 2003), and the folding temperature was $25^{\circ} \mathrm{C}$. The structures were compared with the published ITS structures of Asterochloris photobionts (Kim et al. 2017), and common secondary structures were drawn with PseudoViewer3 (http://pseudoviewer.inha.ac.kr/) and used to identify compensatory base changes (CBCs), hemi-CBCs, and single-base changes.

\section{RESULTS}

\section{Morphology}

Mycobiont specimens collected from King George Island (Antarctica) and Morro Chico (Chile), included Cladonia sp., C. gracilis, Sphaerophorus globosus, and Stereocaulon sp. (Fig. 1). Asterochloris cells among isolates of lichen-forming phycobionts were mostly spherical and occasionally oval in shape (Figs 2-4). The vegetative cells were 4-22 $\mu \mathrm{m}$ in diameter and had thick and smooth cell walls. Occasionally, partially thickened cell walls could 

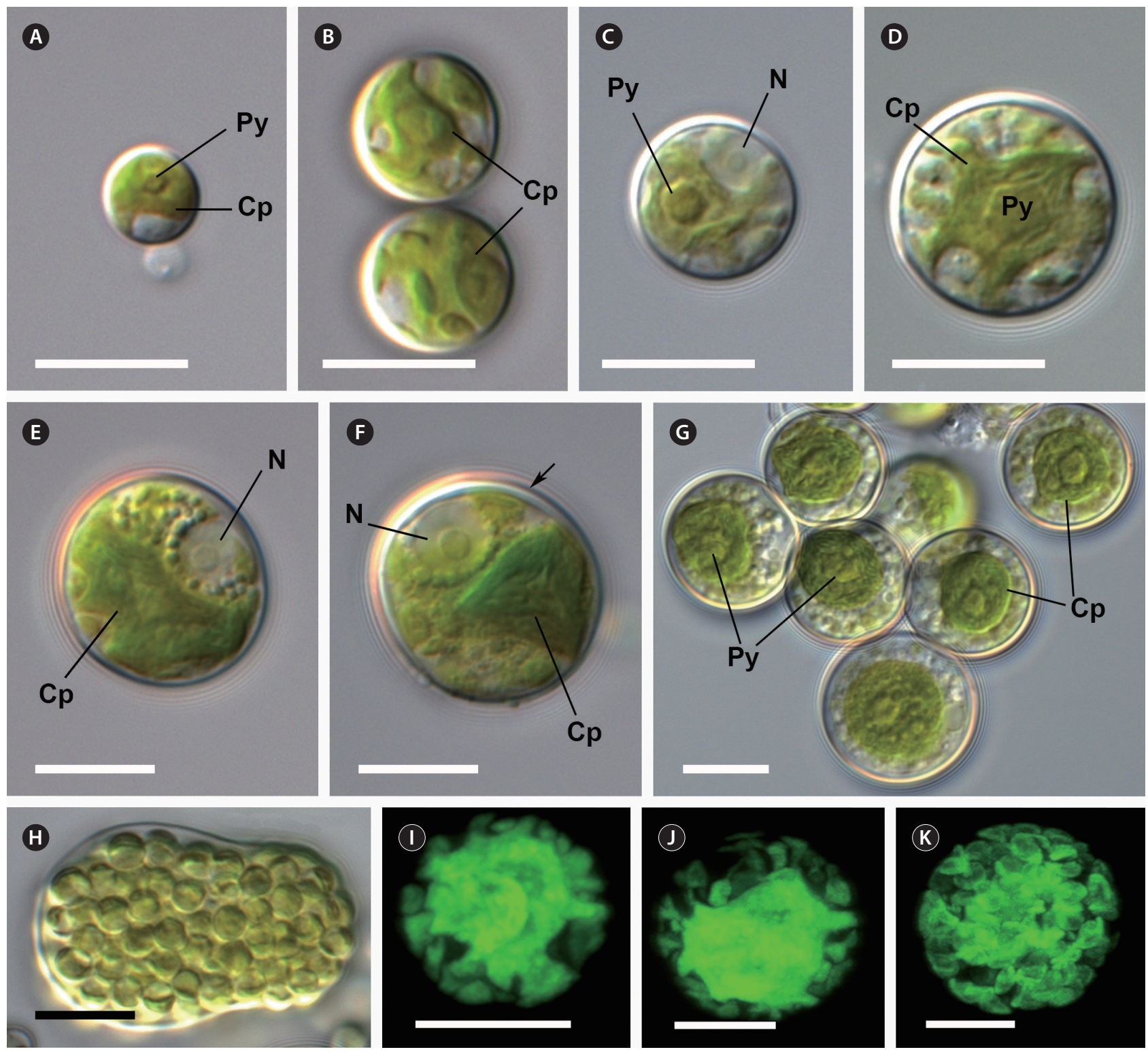

Fig. 2. Light micrographs and confocal reconstructions of the chloroplast structures in Asterochloris antarctica (2015KGS-049A). (A) Mature aplanospore showing a shallowly lobed chloroplast (Cp) and pyrenoid (Py). (B \& C) Young vegetative cells showing shallowly lobed chloroplast, pyrenoid and nucleus (N). (D) Vegetative cell showing a shallowly lobed chloroplast and pyrenoid. (E \& F) Vegetative cells showing chloroplast, peripherally positioned nucleus and thick cell wall (arrow). (G) Vegetative cells showing chloroplasts and pyrenoids. Note starch granules in each cells. (H) Aplanosporangium bearing more than 64 aplanospores. (I-K) Confocal micrographs of chloroplast structures and aplanosporangium. (I) Shallowly lobed chloroplast. (J) Crenulate chloroplast. (K) Aplanosporangium. Scale bars represent: A-K, $10 \mu \mathrm{m}$.

be distinguished in vegetative cells and sporangia. Most of the cell volume was occupied by the chloroplast, which contained one or more pyrenoids. The chloroplast in young cells was positioned parietally and had irregular margins. In mature cells, the chloroplast moved to the center and formed various shapes with different terminals depending on the species. These cells produced either aplanospores or zoospores for reproduction (Figs

\section{$2 \mathrm{H}, 3 \mathrm{H} \& 4 \mathrm{H})$.}

Ultrastructural study was performed using culture strains of three new species to understand pyrenoid characteristic features (Fig. 5). In the case of Asterochloris antarctica (2015KGS-049A), mature cells had few thylakoid tubules in the pyrenoid matrix, which were associated with a few pyrenoglobuli, as seen in the impressatype (Fig. 5A \& B). In mature cells of A. pseudoirregularis 

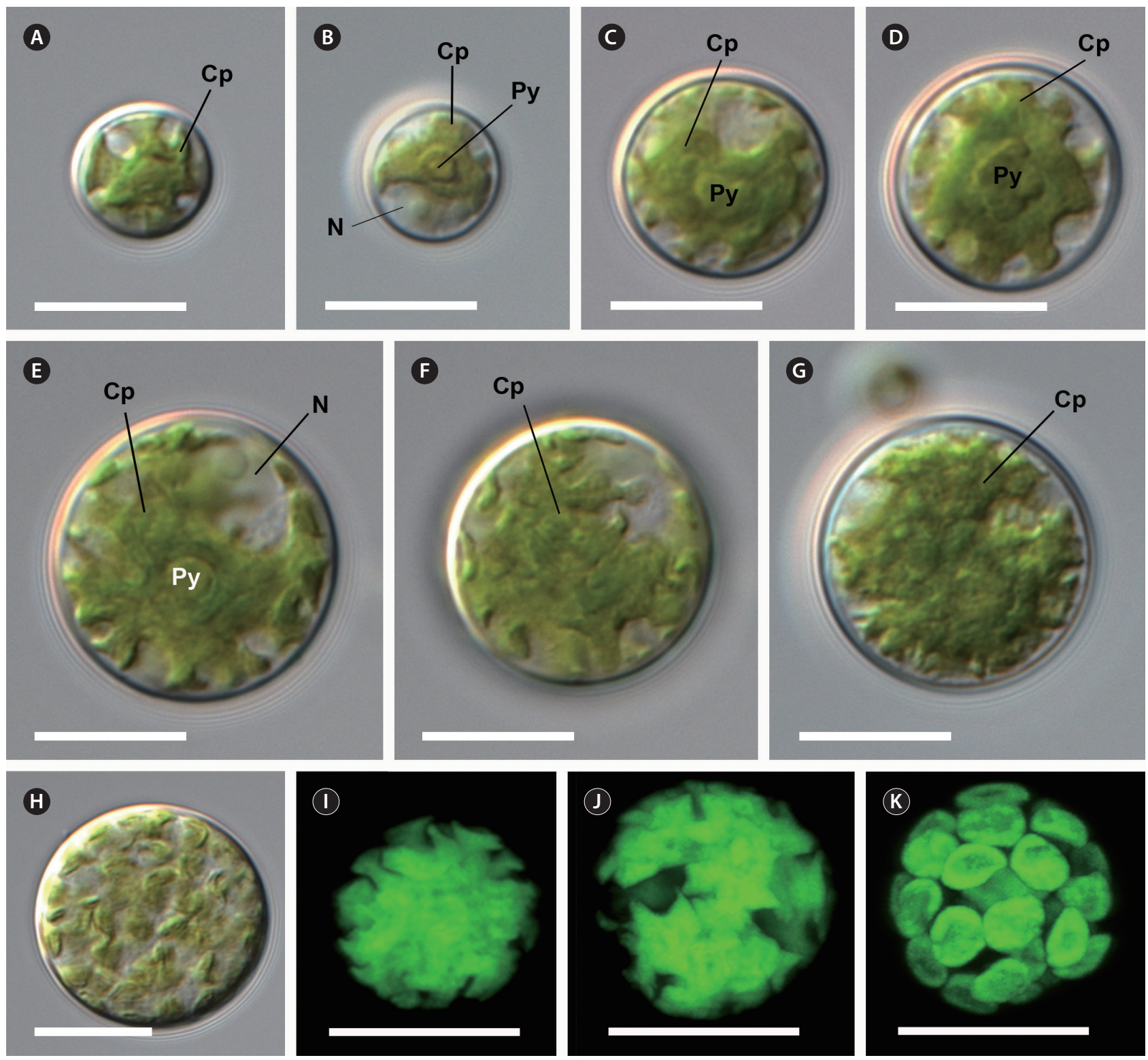

Fig. 3. Light micrographs and confocal reconstructions of the chloroplast structures in Asterochloris pseudoirregularis (2015KGS-064C). (A \& B) Mature aplanospores showing peripheral nucleus (N), shallowly lobed chloroplast (Cp) and pyrenoid (Py). (C-F) Vegetative cells showing pyrenoid positioned in the center of the shallowly lobed chloroplast. (G) Mature vegetative cell showing a shallowly lobed chloroplast with short, pointed terminal. (H) Aplanosporangium. (I-K) Confocal reconstructions of a crenulate chloroplast (I) or shallowly lobed chloroplast with flat ends (J) and aplanospores (K). Scale bars represent: A-K, $10 \mu \mathrm{m}$.

(2015KGS-064C) and A. stereocaulonicola (2015KGIC037A), several thylakoid membranes penetrated into the pyrenoid matrix and connected with many pyrenoglobuli (Fig. 5C-F), consistent with the irregularis-type according to Friedl (1989).

\section{Phylogenetic analysis}

The Bayesian and ML analyses based on the combined dataset of nuclear ITS rDNA and actin and plastid $r b c \mathrm{~L}$ genes revealed 18 well-resolved lineages with high support values (Fig. 6). The 15 formerly described species (Asterochloris erici, A. magna, A. glomerata, A. irregularis, A. excentrica, A. leprarii, A. gaertneri, A. friedlii, A. mediterranea, A. echinata, A. italiana, A. phycobiontica, A. lobophora, A. sejongensis, and A. woessiae) were well recognized and formed their own monophyletic and well-supported lineages. The phylogenetic tree was di- 

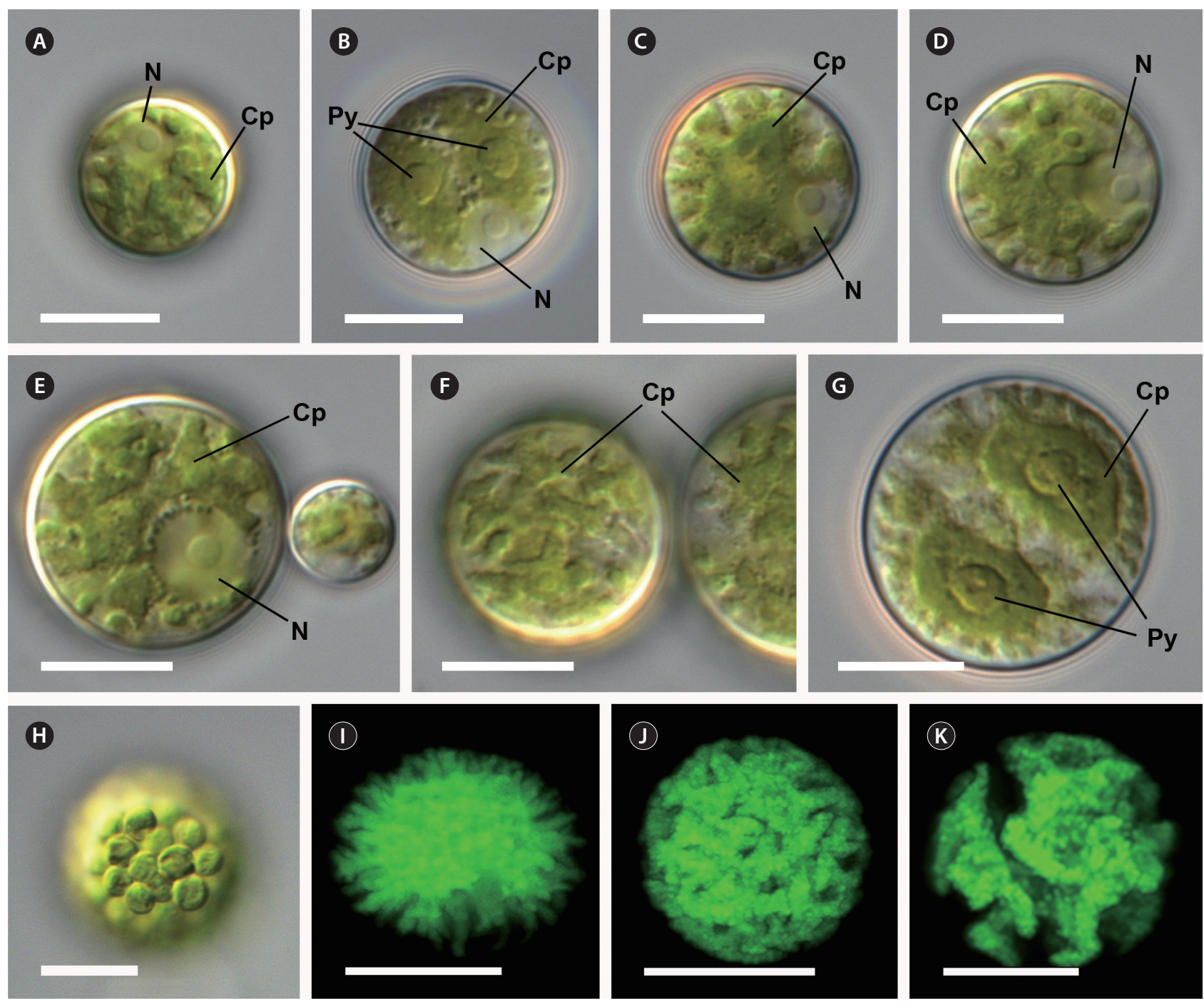

Fig. 4. Light micrographs and confocal reconstructions of the chloroplast structures in Asterochloris stereocaulonicola (2015KGIC-037A). (A) Young vegetative cell showing nucleus $(\mathrm{N})$ and shallowly lobed chloroplast $(\mathrm{Cp})$. (B) Young vegetative cell showing two pyrenoids (Py), shallowly lobed chloroplast and nucleus. (C-E) Vegetative cell showing crenulate chloroplast and nucleus. (F) Surface view of vegetative cell showing the terminals of the chloroplast. (G) Mature vegetative cell showing two crenulate chloroplasts. (H) Aplanosporangium. (I-K) Confocal reconstructions of an echinate chloroplast with pointed ends (I), and a shallowly lobed chloroplast with elongated ends (J \& K). Scale bars represent: A-K, $10 \mu \mathrm{m}$.

vided into two major clades with high support values. The first clade (A) included nine species that were further divided into two subclades $(\mathrm{PP}=1.00, \mathrm{ML}=99)$. The first subclade consisted of five species: A. erici, A. glomerata, A. irregularis, A. magna, and A. pseudoirregularis sp. nov. The new species $A$. pseudoirregularis was sister to $A$. irregularis $(\mathrm{PP}=0.99, \mathrm{ML}=77$ ). The second subclade included four species: A. excentrica, A. stereocaulonicola sp. nov., A. leprarii, and A. gaertneri $(\mathrm{PP}=0.98, \mathrm{ML}=68)$. The second new species, A. stereocaulonicola, was sister to $A$. leprarii $(\mathrm{PP}=1.00, \mathrm{ML}=97)$. The second major clade $(\mathrm{B})$ consisted of 14 lineages. These lineages formed a monophyletic clade with strong support values $(\mathrm{PP}=1.00$, ML = 99), but the relationships among them were not fully resolved. The clade included five undesignated lineages and nine species, including a new species: A. echinata, A. italiana, A. phycobiontica, A. lobophora, A. antarctica sp. nov., A. sejongensis, A. woessiae, A. friedlii, and A. mediterranea. The new species A. antarctica also exhibited a strong sister relationship with $A$. sejongensis and $A$. woessiae $(\mathrm{PP}=1.00, \mathrm{ML}=100)$. 

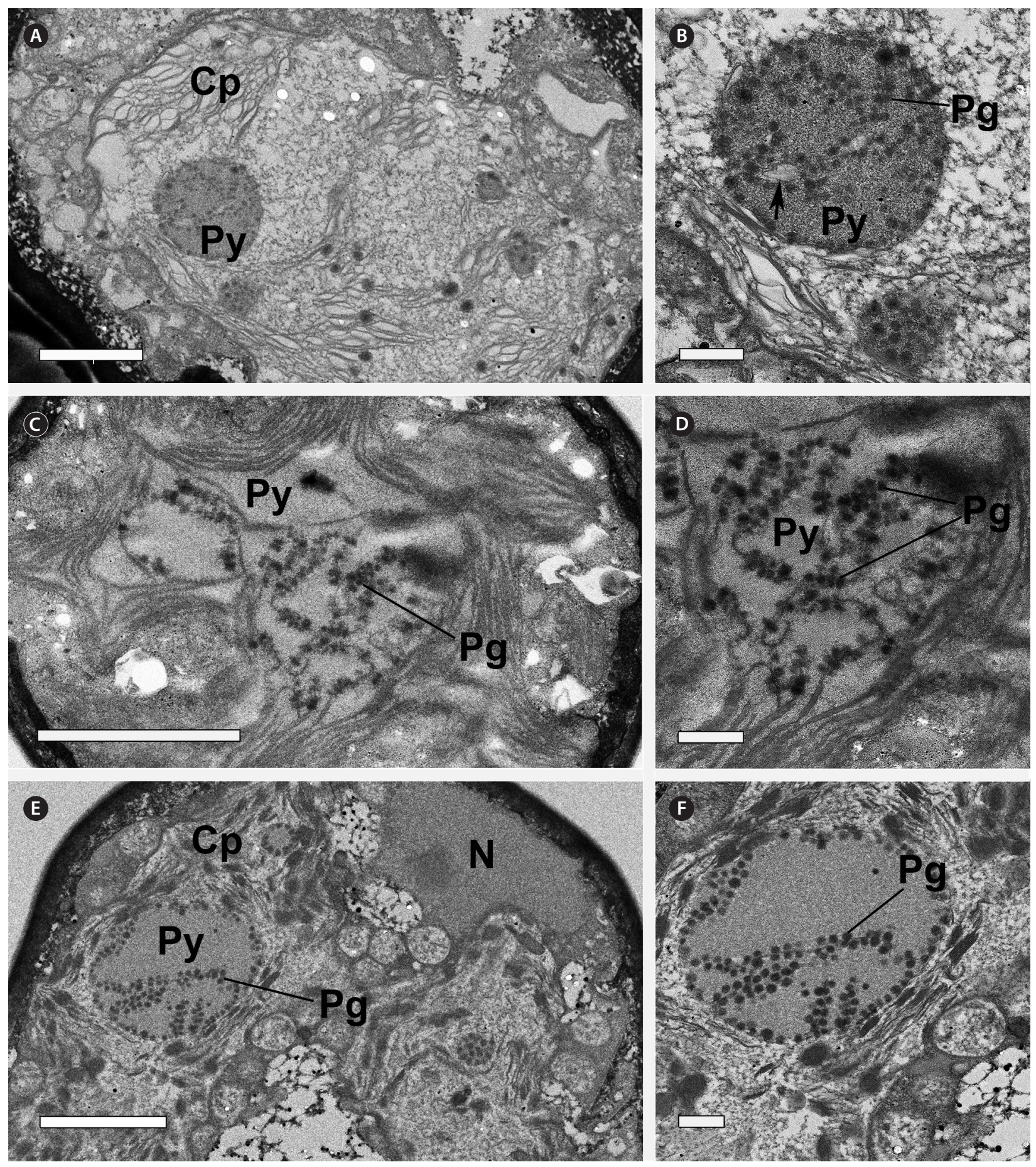

Fig. 5. Transmission electron micrographs of Antarctic photobionts. (A) Chloroplast (Cp) morphology of Asterochloris antarctica (2015KGS-049A). (B) Enlarged image of the pyrenoid (Py) region showing irregularly scattered pyrenoglobuli (Pg) and thylakoid invagination (arrow). (C) Chloroplast of Asterochloris pseudoirregularis (2015KGS-64C). (D) Enlarged image of pyrenoid (Py) in (C) showing pyrenoglobuli (Pg) on the thylakoid membrane. (E) Vegetative cell of Asterochloris stereocaulonicola (2015KGIC-037A). (F) Enlarged image of the pyrenoid region in (E) showing pyrenoglobuli connected with thylakoid membranes. $N$, nucleus. Scale bars represent: $A, C$ \&, $1 \mu \mathrm{m} ; \mathrm{B}, \mathrm{D}$ \& F, $0.5 \mu \mathrm{m}$. 


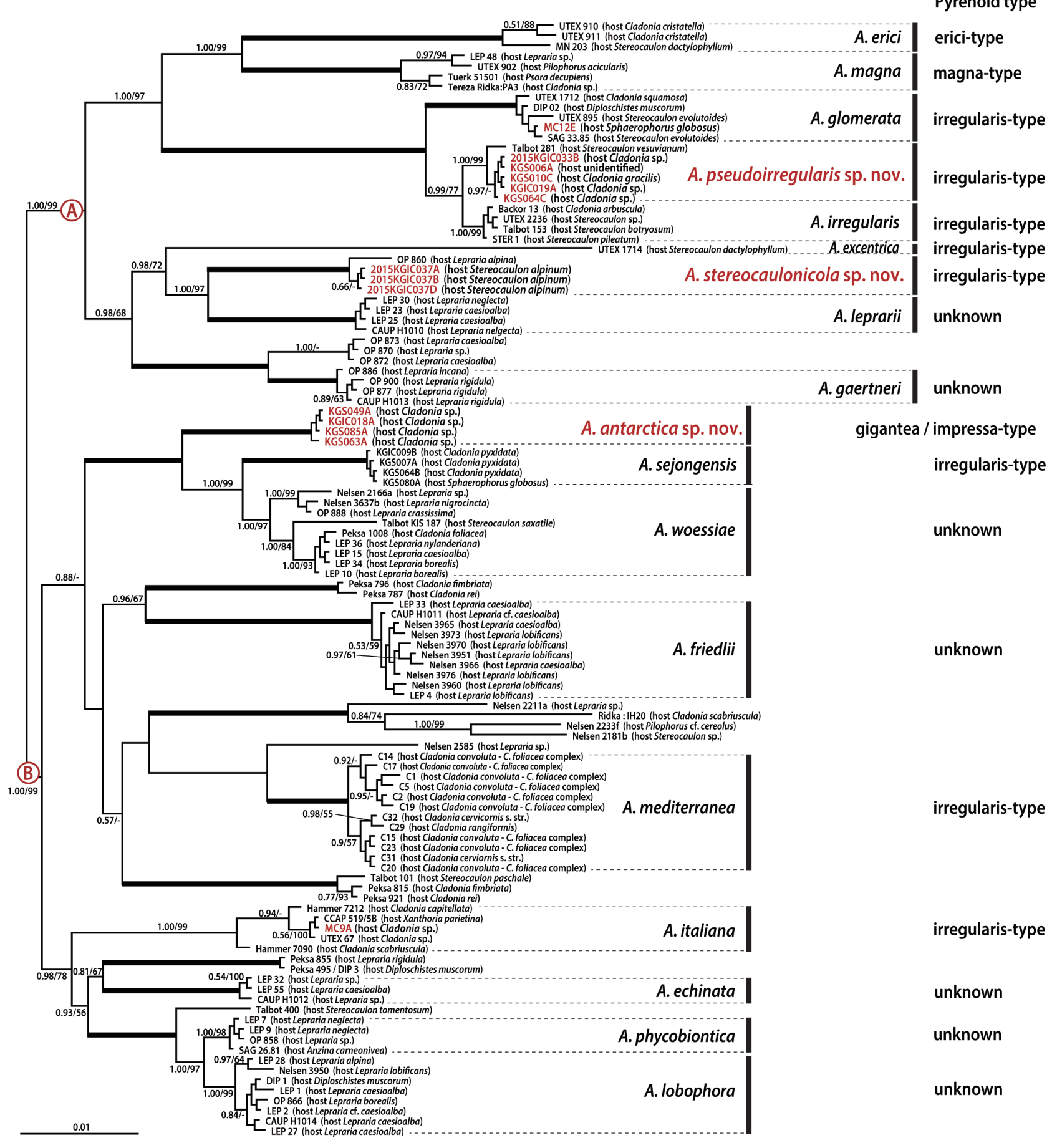

Fig. 6. Bayesian tree based on concatenated nuclear-encoded ITS rDNA, actin and plastid-encoded $r b c L$ sequences. The numbers on each node represent posterior probabilities (PP; left) and maximum likelihood bootstrap values (ML; right) The bold branches have strong support values (PP $=1.00$ and $\mathrm{ML}=100 \%$ ). 


\section{ITS secondary structures}

The nuclear ITS rRNA secondary structures of each new species were compared with those of closely related species to determine the occurrence of CBCs (nucleotide changes on both sides of a paired base) and hemi-CBCs (change on only one side of the nucleotide pair, with the pairing preserved) according to Coleman (2000, 2003) and Ma et al. (2015). The ITS1 secondary structure was composed of four paired regions (helices I-IV, see Fig. 7A-F). In A. antarctica, the base changes were compared with those in the ITS1 and ITS2 secondary structures of A. sejongensis (Fig. 7A \& B). In ITS1 (Fig. 7A), the bases were different in helix I (UCC - UUCUCC), in helix II (C:G - U:G), and in helix IV (U:U - U:C). In ITS2 (Fig. 7B), the bases were different in helix I (UACA - CAUG), between helix II and helix III (AU - AGU), in helix III (C:G - U:G), and in helix IV (A:U - A:C). The ITS1 and ITS2 secondary structures of A. pseudoirregularis were compared with those of A. irregularis (Fig. 7C \& D). The base differences of A. pseudoirregularis in helix II (GCUUGC - UCUUGC) and in helix IV (AAUU - AUUU) were detected only in ITS1 (Fig. 7C). The ITS1 and ITS2 secondary structures of A. stereocaulonicola were compared with those of $A$. leprarii (Fig. 7E \& F). In ITS1 (Fig. 7E), the bases were different in helix I (UUCAC - UUUAC), in helix II (G:U - A:U and CUUG - CCUG), and in helix IV (UUCAAACCAAUAUC - UUCAAACCAAUACU). In ITS2 (Fig. 7F), the bases were different in helix I (CCC - CCA), in helix III (UUGAU - UUAAU and CCUGU - CUUGU) and between helix IV and the LSU rDNA (UUCAAAUU - UCUAAUU). The above three species had conserved motifs (Mai and Coleman 1997) that included a UU mismatch in helix II and a UGGU sequence in helix III of ITS2 (Fig. 7B, D \& F).

\section{Taxonomy}

\section{Taxon descriptions.}

\section{Asterochloris antarctica Y. J. Kim, J. I. Kim et W. Shin sp.} nov.

Cells are mostly spherical in shape. Vegetative cells are 6-19 $\mu \mathrm{m}$ in diameter. Cells have thick and flat cell walls (Fig. 2A-G). Occasionally, a partially thickened cell wall can be distinguished. Most of the cell volume is taken up by the chloroplast (Fig. 2A-F). Chloroplast in young cells is positioned parietally with irregular margins and has one or two pyrenoids (Fig. 2A, C, D \& G). In mature cells, the chloroplast is in the center and is shallowly lobe-shaped with elongated terminals (Fig. 2D \& E) or crenulate (Fig. 2I \& J). This species produces 64-128 apla- nospores for asexual reproduction (Fig. 2H \& K). Rarely, zoospores burst from oval or spherical sporangia.

Molecular signatures. Base changes (UCC-UUCUCC) in helix I of ITS1 (Fig. 7A) and base changes (UACA CAUG) in helix I and (A:U - A:C) in helix IV of ITS2 (Fig. 7B). Structures were compared with those of the ITS1 and ITS2 secondary transcripts of A. sejongensis, a closely related sister taxon in the tree.

Holotype. Deposited in the herbarium of Chungnam National University, Daejeon, Korea (CNUK).

Type strain. Deposited in the culture collection of Chungnam National University (strain number: 2015KGS-049A).

Type locality. Phycobiont of Cladonia sp. collected from rocks and soil crusts at King Sejong Station, King George Island, Antarctica (-62.135100 S, -58.467100 W), in February 2015 and 2016. The lichen specimens have been deposited in the herbarium of the Korea Polar Research Institute (2015KGS-049A, 2015KGS-063A, 2015KGS-085A, and 2016KGIC-018A).

Etymology. The specific epithet "antarctica" is derived from the name Antarctica, corresponding to the geographic origin of this photobiont.

Distribution. Currently, the only known distribution area is in the King George Island, Antarctica.

Ecology. In Cladonia lichens growing on gravelly soil and mosses.

Asterochloris pseudoirregularis Y. J. Kim, J. I. Kim et W. Shin sp. nov.

Cells are mostly spherical in shape. Vegetative cells are 4-18 $\mu \mathrm{m}$ in diameter. Cells have thick and flat cell walls (Fig. 3A-G). Cells at the sporangium stage occasionally have partially thickened cell walls. Most of the cell volume is occupied by the chloroplast-bearing one central pyrenoid (Fig. 3B-E). Chloroplast in young cells is positioned parietally and deeply lobed with irregular margins (Fig. 3E-G) while in mature cells, the chloroplast is located in the center of the cell (Fig. 3D \& E). Chloroplast is shallowly or deeply lobed or crenulate (Fig. 3A-G) with flat or elongated terminals (Fig. 3E, F, I \& J). This species produces 64-128 aplanospores for asexual reproduction (Fig. 3H \& K). Rarely, zoospores are released from oval or spherical sporangia.

Molecular signatures. Base changes (GCUUGC UCUUGC) in helix II and base changes (AAUU - AUUU) in helix IV of ITS1 (Fig. 7C). Structures were compared with those of the ITS1 secondary transcripts of A. irregularis.

Holotype. Deposited in the herbarium of Chungnam 

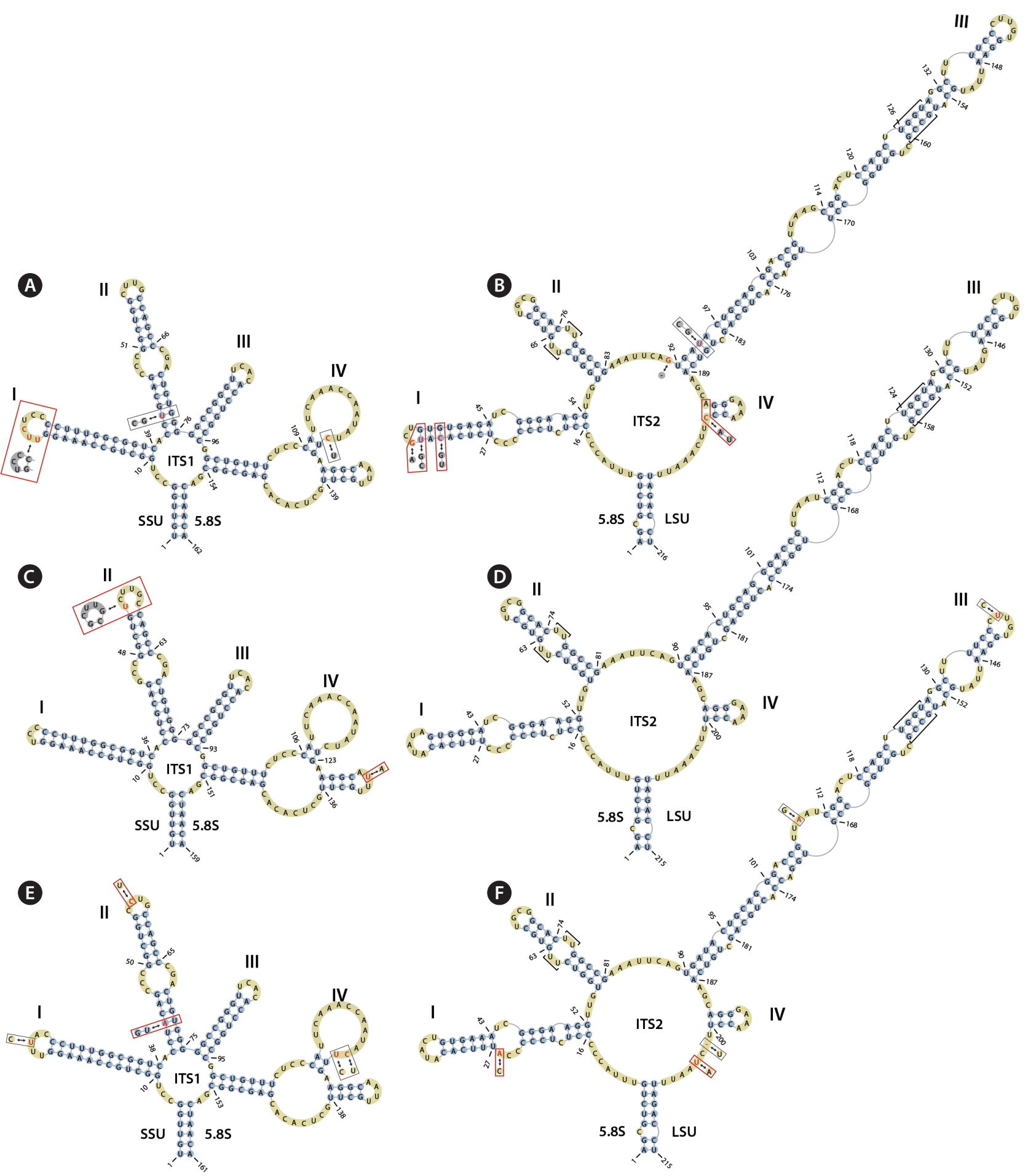

Fig. 7. Predicted secondary structures of the internal transcribed spacer (ITS) 1 and ITS2 transcripts of Antarctic Asterochloris species. (A \& B) Predicted secondary structures of the ITS1 (A) and ITS2 (B) transcripts of $A$. antarctica (2015KGS-049A) drawn by comparison with those of the closely related species $A$. sejongensis. Base changes of Asterochloris species are indicated in red. (C \& D) Predicted secondary structures of the ITS1 (C) and ITS2 (D) transcripts of A. pseudoirregularis (2015KGS-064C) drawn by comparison with those of the closely related species $A$. irregularis. (E \& F) Predicted secondary structures of the ITS1 (A) and ITS2 (B) transcripts of $A$. stereocaulonicola (2015KGIC-037A) drawn by comparison with those of the closely related species $A$. leprarii. Base changes between two Asterochloris genotypes are indicated: the black boxes indicate base changes, and the red boxes indicate base changes in each new species that can serve as diagnostic molecular signatures. ITS2 transcripts, highly conserved U-U mismatches and UGGU motifs are marked with [ ]. 
National University, Daejeon, Korea (CNUK).

Type strain. Deposited in the culture collection of Chungnam National University (strain number: 2015KGS-064C).

Type locality. Samples of Cladonia sp. and Cladonia gracilis were collected from rocks and soil crusts in the vicinity of King Sejong Station, King George Island, Antarctica (-62.131490 S, -58.459550 W), in February 2015 and 2016. The lichen specimens have been deposited in the herbarium of the Korea Polar Research Institute (2015KGS-010C, 2015KGS-006A, 2015KGS-064C, 2015KGIC-033B, and 2016KGIC-019A).

Etymology. The specific epithet "pseudoirregularis" is derived from that of the species A. irregularis and Greek "pseudo-" (= false) indicating the high similarity with this species.

Distribution. Currently, the only known distribution area is in the King George Island, Antarctica.

Ecology. In Cladonia gracilis commonly growing on gravelly soil and mosses.

Asterochloris stereocaulonicola Y. J. Kim, J. I. Kim et W. Shin sp. nov.

Cells are mostly spherical and occasionally oval in shape (Fig. 4). Vegetative cells are approximately 9-22 $\mu \mathrm{m}$ in diameter. Cells have thick and flat cell walls (Fig. 4A-F). Occasionally, the cell wall is partially thickened. Most of the cell volume is taken up by the chloroplast (Fig. 4). Chloroplast has one or two pyrenoids. Chloroplast in young cells is positioned parietally, with irregular margins. In mature cells, the chloroplast is moved to the center of the cell and is echinate with pointed terminals (Fig. $4 \mathrm{H}$ ) or shallowly or deeply lobed with elongated terminals (Fig. 4B-E). This species produces 64-128 aplanospores for asexual reproduction. Rarely, zoospores are released from oval or spherical sporangia.

Molecular signatures. Hemi-CBCs (G:U - A:U) and base changes (CUUG - CCUG) in helix II and base changes (UUCAAACCAAUAUC - UUCAAACCAAUACU) in helix IV of ITS1 (Fig. 7E) and base changes (CCC - CCA) in helix 1 and base changes (UUCAAAUU - UCUAAUU) between helix IV and the LSU rDNA region in ITS2 (Fig. 7F). Structures were compared with those of the ITS1 and ITS2 secondary transcripts of $A$. leprarii.

Holotype. Deposited in the herbarium of Chungnam National University, Daejeon, Korea (CNUK).

Type strain. Deposited in the culture collection of Chungnam National University (strain number: 2015KGIC-037A).

Type locality. Phycobiont of Stereocaulon sp. col- lected from rocks, mosses and soil crusts in the vicinity of King Sejong Station, King George Island, Antarctica (-62.131230 S, -58.458890 W), in February 2015. The lichen specimens have been deposited in the herbarium of the Korea Polar Research Institute (2015KGIC-037A, 2015KGIC-037B, and 2015KGIC-037D).

Etymology. The name "stereocaulonicola" refers to the genus name of the fungal partner Stereocaulon and Greek "-cola" (= dweller).

Distribution. Currently, the known distribution area is in the King George Island, Antarctica.

Ecology. In Stereocaulon species growing on rocks, scrubland, and soil on Barton Peninsula, King George Island.

\section{DISCUSSION}

Although more than 19,400 species (ca. $27 \%$ of all known fungi) of lichen-forming fungi are known (Jaklitsch et al. 2016, Lücking et al. 2017), lichen-associated photobiont diversity is still underestimated (Muggia et al. 2018). In particular, being an extremely harsh environment, Antarctica is covered mostly by mosses, lichens, green algae and only two flowering plants, which thrive in the coldest, driest and windiest climates (LaybournParry and Pearce 2007, Convey et al. 2009, Chae et al. 2019). On this inhospitable continent, the diversity of phycobiont species in the genus Asterochloris has been studied only once so far (Kim et al. 2017), but few studies on Trebouxia have been already performed (Romeike et al. 2002, Fernández-Mendoza et al. 2011, Pérez-Ortega et al. 2012, Ruprecht et al. 2012). In this study, we discovered three new Asterochloris species associated with the lichenized fungal genera Cladonia, Sphaerophorus, and Stereocaulon in the vicinity of King Sejong Station (King George Island, Antarctica). These new species were differentiated from other species by morphological and molecular data.

Among the common green algal genera of lichen photobionts, Asterochloris has consisted of 15 species and is more closely related to the recently established genus Vulcanochloris than to Trebouxia and Myrmecia (Vančurová et al. 2015). However, both Asterochloris and Vulcanochloris can be differentiated by morphological and molecular characteristics. The genus Vulcanochloris is characterized by the unique formation of spherical incisions within the pyrenoid and by forming a strongly supported monophyletic lineage in Bayesian trees based on $r b c$ L and ITS data, respectively (Vančurová et al. 2015), 
but the pyrenoid type may be similar to the corticolartype according to Friedl (1989). Chloroplast and pyrenoid types are important diagnostic features for species delimitation among the species of the genus Asterochloris (Gärtner 1985, Friedl 1989, Škaloud et al. 2015). Asterochloris has multiple chloroplast types depending on developmental stage and species. Our new species also have various chloroplast morphologies and share chloroplast features with previously described Asterochloris species (Škaloud et al. 2015).

The new species Asterochloris antarctica grouped with A. sejongensis and A. woessiae and was characterized by spherical cells possessing shallowly lobed and / or crenulate chloroplasts with flat terminals. Based on comparisons with closely related species, A. antarctica shared the crenulate chloroplast and spherical cell shape characters with $A$. sejongensis. However, A. antarctica did not have deeply lobed and / or echinate chloroplasts or oval or pyriform cells. The new species was differentiated from A. woessiae based on its deeply lobed chloroplasts with flat terminals. Compared with the ITS secondary structures of $A$. sejongensis, those of $A$. antarctica had a base change in helix I of ITS 1 and base changes in helix 1 and helix IV of ITS2 (see Fig. 7). Although these species were closely related, they had morphological differences and unique molecular signatures in terms of ITS rRNA secondary structures, suggesting that $A$. antarctica is differentiated from A. sejongensis.

A. pesudoirregularis had shallowly and / or deeply lobed or crenulate chloroplasts and spherical cells. Based on comparisons with closely related species, A. pesudoirregularis was similar to $A$. irregularis in having shallowly and / or deeply lobed chloroplasts and spherical cells, but $A$. pesudoirregularis did not have oval or pyriform cells. Compared with the ITS secondary structures of $A$. irregularis, those of $A$. pesudoirregularis had base changes in helix II, and one single-base change in helix IV of ITS1. Although these two species are closely related, they have morphological differences and unique molecular signatures, suggesting that $A$. pesudoirregularis is different from A. irregularis.

The new species Asterochloris stereocaulonicola was characterized by spherical or oval cells, with vegetative cells possessing echinate chloroplasts with pointed terminals or shallowly and / or deeply lobed chloroplasts with elongated terminals. Compared with a closely related species, A. leprarii, the new species has distinctive echinate chloroplasts. Compared with the ITS secondary structures of A. leprarii, those of A. stereocaulonicola had a hemi-CBC and base change in helix I of ITS1 and base changes in helix 1 and (UUCAAAUU - UCUAAUU) between helix IV and the LSU rRNA of ITS2. Although these two species are closely related, they have morphological differences and many unique molecular signatures, suggesting that $A$. stereocaulonicola is differentiated from $A$. leprarii.

In ultrastructural studies of chloroplasts, the thylakoid membranes in the pyrenoid matrix were associated with pyrenoglobuli (Fisher and Lang 1971), and the form and arrangement of chloroplast thylakoids was divided into six categories (Friedl 1989). However, these patterns were not reflected in the phylogenetic relationships among the species. According to the morphological type of pyrenoids described by Friedl (1989), two new species, namely, A. pseudoirregularis and A. streocaulonicola, had irregularis-type pyrenoids, while A. antarctica had gigantea- or impressa-type pyrenoids. When the pyrenoid types were mapped onto our Bayesian tree, the ultrastructure data were not congruent with the phylogenetic tree, suggesting that diverse pyrenoid types may have arisen independently in the evolutionary history of the genus Asterochloris. For example, irregularis-type pyrenoids were distributed in diverse clades in our phylogenetic tree (Fig. 6): A. excentrica, A. glomerata, A. irregularis, A. italiana, A. pseudoirregularis, A. sejongensis, and A. stereocaulonicola. A. antarctica has gigantea- and impressa-type pyrenoids, but $A$. sejongensis has irregularis-type pyrenoids, even though the two species are included in the same lineage.

In summary, the phylogenetic tree based on the combined nuclear ITS, actin, and $r b c \mathrm{~L}$ sequence data had a topology similar to that of recently published phylogenies (Moya et al. 2015, Škaloud et al. 2015, Kim et al. 2017), and the genus was largely divided into two clades with moderate to high support values. The phylogenetic relationships among the members of Asterochloris were not fully resolved in clade B of our tree, but each species formed a monophyletic clade despite the morphology being misleading for species identification. Compared with closely related species, the three new species had unique $\mathrm{CBCs}$, hemi-CBCs and single-base changes in ITS secondary structures, supporting that the new species were differentiated from closely related species in the tree.

\section{ACKNOWLEDGEMENTS}

This study was supported by the Korea Polar Research Institute (PE15020) and the National Research Founda- 
tion (NRF) of Korea (2019R1I1A2A01063159) to W. Shin.

\section{SUPPLEMENTARY MATERIALS}

Supplementary Table S1. Strains of the genus Asterochloris taxa used in this study and the GenBank accession numbers for their nuclear ITS rDNA, actin, and plastid $r b c \mathrm{~L}$ gene sequences (https://e-algae.org).

\section{REFERENCES}

Ahmadjian, V. 1960. Some new and interesting species of Trebouxia, a genus of lichenized algae. Am. J. Bot. 47: 677-683.

Ahmadjian, V. 1967. A guide to the algae occurring as lichen symbionts: isolation, culture, cultural physiology, and identification. Phycologia 6:127-160.

Archibald, P. A. 1975. Trebouxia de Pulmaly (Chlorophyceae, Chlorococcales) and Pseudotrebouxia gen. nov. (Chlorophyceae, Chlorosarcinales). Phycologia 14:125-137.

Beck, A., Bechteler, J., Casanova-Katny, A. \& Dzhilyanova, I. 2019. The pioneer lichen Placopsis in maritime Antarctica: genetic diversity of their mycobionts and green algal symbionts, and their correlation with deglaciation time. Symbiosis 79:1-24.

Borchhardt, N., Schiefelbein, U., Abarca, N., Boy, J., Mikhailyuk, T., Sipman, H. J. M. \& Karsten, U. 2017. Diversity of algae and lichens in biological soil crusts of Ardley and King George islands, Antarctica. Antarct. Sci. 29:229237.

Chae, H., Lim, S., Kim, H. S., Choi, H. G. \& Kim, J. H. 2019. Morphology and phylogenetic relationships of Micractinium (Chlorellaceae, Trebouxiophyceae) taxa, including three new species from Antarctica. Algae 34:267-275.

Chodat, R. 1913. Monographies d'Algues en Culture Pure. Matériaux Pour la Flore Cryptogamique Suisse, Vol. 4, Fasc. 2. K.J. Wyss, Berne, $266 \mathrm{pp}$.

Coleman, A. W. 2000. The significance of a coincidence between evolutionary landmarks found in mating affinity and a DNA sequence. Protist 151:1-9.

Coleman, A. W. 2003. ITS2 is a double-edged tool for eukaryote evolutionary comparisons. Trends Genet. 19:370375.

Convey, P., Stevens, M. I., Hodgson, D. A., Smellie, J. L., Hillenbrand, C. -D., Barnes, D. K. A., Clarke, A., Pugh, P. J. A., Linse, K. \& Cary, S. C. 2009. Exploring biological constraints on the glacial history of Antarctica. Quat. Sci. Rev. 28:3035-3048.
Culberson, C. F. 1972. Improved conditions and new data for the identification of lichen products by a standardized thin-layer chromatographic method. J. Chromatogr. 72:113-125.

Elbert, W., Weber, B., Burrows, S., Steinkamp, J., Büdel, B., Andreae, M. O. \& Pöschl, U. 2012. Contribution of cryptogamic covers to the global cycles of carbon and nitrogen. Nat. Geosci. 5:459-462.

Engelen, A., Convey, P., Popa, O. \& Ott, S. 2016. Lichen photobiont diversity and selectivity at the southern limit of the maritime Antarctic region (Coal Nunatak, Alexander Island). Polar Biol. 39:2403-2410.

Fernández-Mendoza, F., Domaschke, S., García, M. A., Jordan, P., Martín, M. P. \& Printzen, C. 2011. Population structure of mycobionts and photobionts of the widespread lichen Cetraria aculeata. Mol. Ecol. 20:12081232.

Fisher, K. A. \& Lang, N. J. 1971. Ultrastructure of the pyrenoid of Trebouxia in Ramalina menziesii Tuck. J. Phycol. 7:25-37.

Friedl, T. 1989. Comparative ultrastructure of pyrenoids in Trebouxia (Microthamniales, Chlorophyta). Plant Syst. Evol. 164:145-159.

Friedl, T. 1995. Inferring taxonomic positions and testing genus level assignments in coccoid green lichen algae: a phylogenetic analysis of $18 \mathrm{~S}$ ribosomal RNA sequences from Dictyochloropsis reticulata and from members of the genus Myrmecia (Chlorophyta, Trebouxiophyceae cl. nov.). J. Phycol. 31:632-639.

Friedl, T. \& Büdel, B. 2008. Photobionts. In Nash, T. H. (Ed.) Lichen Biology. 2nd ed. Cambridge University Press, Cambridge, pp. 9-26.

Friedl, T. \& Rokitta, C. 1997. Species relationships in the lichen alga Trebouxia (Chlorophyta, Trebouxiophyceae): molecular phylogenetic analyses of nuclear encoded large subunit rRNA gene sequences. Symbiosis 23:125148.

Friedl, T. \& Zeltner, C. T. 1994. Assessing the relationships of some coccoid green lichen algae and the Microthamniales (Chlorophyta) with $18 \mathrm{~S}$ ribosomal RNA gene sequence comparisons. J. Phycol. 30:500-506.

Garrido-Benavent, I. \& Pérez-Ortega, S. 2017. Past, present, and future research in bipolar lichen-forming fungi and their photobionts. Am. J. Bot. 104:1660-1674.

Garrido-Benavent, I., Pérez-Ortega, S. \& de los Ríos, A. 2017. From Alaska to Antarctica: Species boundaries and genetic diversity of Prasiola (Trebouxiophyceae), a foliose chlorophyte associated with the bipolar lichen forming fungus Mastodia tessellata. Mol. Phylogenet. Evol. 107:117-131. 
Gärtner, G. 1985. Taxonomische problem bei den flechtenalgengattungen Trebouxia und Pseudotrebouxia (Chlorophyceae, Chlorellales). Phyton 25:101-111.

Honegger, R. 2012. The symbiotic phenotype of lichenforming Ascomycetes and their endo- and epibionts. In Hock, B. (Ed.) The Mycota, Vol. 9. Springer, Berlin, pp. 287-339.

Jaag, O. 1929. Recherches expérimentales sur les gonidies des lichens appurtenant aux genres Parmelia et Cladonia. Bull. Trav. Soc. bot. Genève 21:1-119.

Jaklitsch, W. M., Baral, H. O., Lücking, R. \& Lumbsch, H. T. 2016. Ascomycota. In Frey, W. (Ed.) Syllabus of Plant Families: Adolf Engler's Syllabus der Pflanzenfamilien. Borntraeger, Stuttgart, pp. 1-322.

Kim, J. I., Nam, S. W., So, J. E., Hong, S. G., Choi, H. -G. \& Shin, W. 2017. Asterochloris sejongensis sp. nov. (Trebouxiophyceae, Chlorophyta) from King George Island, Antarctica. Phytotaxa 295:60-70.

Kirk, P. M., Cannon, P. F., Minter, D. W. \& Stalpers, J. A. 2008. Ainsworth \& Bisby's dictionary of the fungi. 10th ed. Cromwell Press, Trowbridge, $771 \mathrm{pp}$.

Kroken, S. \& Taylor, J. W. 2000. Phylogenetic species, reproductive mode, and specificity of the green alga Trebouxia forming lichens with the fungal genus Letharia. Bryologist 103:645-660.

Laybourn-Parry, J. \& Pearce, D. A. 2007. The biodiversity and ecology of Antarctic lakes: models for evolution. Phil. Trans. R. Soc. B 362:2273-2289.

Lücking, R., Hodkinson, B. P. \& Leavitt, S. D. 2017. Corrections and amendments to the 2016 classification of lichenized fungi in the Ascomycota and Basidiomycota. Bryologist 120:58-69.

Ma, S., Han, B., Huss, V. A. R., Hu, X., Sun, X. \& Zhang, J. 2015. Chlorella thermophila (Trebouxiophyceae, Chlorophyta), a novel thermo-tolerant Chlorella species isolated from an occupied rooftop incubator. Hydrobiologia 760:81-89.

Mai, J. C. \& Coleman, A. W. 1997. The internal transcribed spacer 2 exhibits a common secondary structure in green algae and flowering plants. J. Mol. Evol. 44:258271.

Moya, P., Škaloud, P., Chiva, S., García-Breijo, F. J., Reig-Armiñana, J., Vančurová, L. \& Barreno, E. 2015. Molecular phylogeny and ultrastructure of the lichen microalga Asterochloris mediterranea sp. nov. from Mediterranean and Canary Islands ecosystems. Int. J. Syst. Evol. Microbiol. 65:1838-1854.

Muggia, L., Leavitt, S. \& Barreno, E. 2018. The hidden diversity of lichenized Trebouxiophyceae (Chlorophyta). Phycologia 57:503-524.
Nägeli, C. 1849. Gattungen einzelliger Algen, physiologisch und systematisch bearbeitet. Neue Denkschriften der Allg. Schweizerischen Gesellschaft für die Gesammten Naturwissenschaften 10:1-139.

Olech, M. 2004. Lichens of King George Island, Antarctica. The Institute of Botany of the Jagiellonian University, Kraków, 391 pp.

Orange, A., James, P. W. \& White, F. J. 2001. Microchemical methods for identification of lichens. British Lichen Society, London, $101 \mathrm{pp}$.

Øvstedal, D. O. \& Smith, R. I. L. 2001. Lichens of Antarctica and South Georgia: a guide to their identification and ecology. Cambridge University Press, Cambridge, 424 pp.

Pérez-Ortega, S., Ortiz-Álvarez, R., Allan Green, T. G. \& de Los Ríos, A. 2012. Lichen myco- and photobiont diversity and their relationships at the edge of life (McMurdo Dry Valleys, Antarctica). FEMS Microbiol. Ecol. 82:429-448.

Piercey-Normore, M. D. \& DePriest, P. T. 2001. Algal switching among lichen symbioses. Am. J. Bot. 88:1490-1498.

Puymaly, A. de. 1924. Le Chlorococcum humicola (Naeg.) Rabenh. Rev. Algol. 2:107-114.

Raths, H. 1938. Experimentelle Untersuchungen mit Flechtengonidien der Familie der Caliciaceen. Ber. Schweiz. Bot. Ges. 48:329-416.

Reynolds, E. S. 1963. The use of lead citrate at high $\mathrm{pH}$ as an electron-opaque stain in electron microscopy. J. Cell Biol. 17:208-212.

Richardson, D. H. S. \& Smith, D. C. 1968. Lichen physiology. IX. Carbohydrate movement from the Trebouxia symbiont of Xanthoria aureola to the fungus. New Phytol. 67:61-68.

Richardson, D. H. S., Smith, D. C. \& Lewis, D. H. 1967. Carbohydrate movement between the symbionts of lichens. Nature 214:879-882.

Romeike, J., Friedl, T., Helms, G. \& Ott, S. 2002. Genetic diversity of algal and fungal partners in four species of Umbilicaria (lichenized ascomycetes) along a transect of the Antarctic Peninsula. Mol. Biol. Evol. 19:1209-1217.

Ronquist, F., Teslenko, M., van der Mark, P., Ayres, D. L., Darling, A., Höhna, S., Larget, B., Liu, L., Suchard, M. A. \& Huelsenbeck, J. P. 2012. MrBayes 3.2: efficient Bayesian phylogenetic inference and model choice across a large model space. Syst. Biol. 61:539-542.

Ruprecht, U., Brunauer, G. \& Printzen, C. 2012. Genetic diversity of photobionts in Antarctic lecideoid lichens from an ecological view point. Lichenologist 44:661-678.

Schwendener, S. 1867. Über die wahre Natur der Flechtengonidien. Verh. Schweiz. Naturforsch. Ges. 51:88-90.

Sherwood, A. R., Garbary, D. J. \& Sheath, R. G. 2000. Assess- 
ing the phylogenetic position of the Prasiolales (Chlorophyta) using $r b c \mathrm{~L}$ and $18 \mathrm{~S}$ rRNA gene sequence data. Phycologia 39:139-146.

Škaloud, P. \& Peksa, O. 2010. Evolutionary inferences based on ITS rDNA and actin sequences reveal extensive diversity of the common lichen alga Asterochloris (Trebouxiophyceae, Chlorophyta). Mol. Phylogenet. Evol. 54:3646.

Škaloud, P., Steinova, J., Ridka, T., Vančurová, L. \& Peksa, O. 2015. Assembling the challenging puzzle of algal biodiversity: species delimitation within the genus Asterochloris (Trebouxiophyceae, Chlorophyta). J. Phycol. 51:507-527.

Smith, S. W., Overbeek, R., Woese, C. R., Gilbert, W. \& Gillevet, P. M. 1994. The genetic data environment an expandable GUI for multiple sequence analysis. Comput. Appl. Biosci. 10:671-675.

Stamatakis, A. 2014. RAxML version 8: a tool for phylogenetic analysis and post-analysis of large phylogenies. Bioinformatics 30:1312-1313.

Thomas, D. L. \& Montes, J. G. 1978. Spectrophotometrically assayed inhibitory effects of mercuric compounds on Anabaena flos-aquae and Anacystis nidulans (Cyanophyceae). J. Phycol. 14:494-499.

Treboux, O. 1912. Die freilebende Alge und die Gonidie Cystococcus humicola in bezug auf die Flechtensymbiose. Ber. Deutsc. Bot. Ges. 30:69-80.
Tschermak-Woess, E. 1980. Asterochloris phycobiontica, gen. et spec., nov., der Phycobiont der Flechte Varicellaria carneonivea. Plant Syst. Evol. 135:279-294.

Tschermak-Woess, E. 1988. The algal partner. In Galun, M. (Ed.) CRC Handbook of Lichenology, Vol. 1. CRC Press, Boca Raton, FL, pp. 39-92.

Vančurová, L., Peksa, O., Němcová, Y. \& Škaloud, P. 2015. Vulcanochloris (Trebouxiales, Trebouxiophyceae), a new genus of lichen photobiont from La Palma, Canary Islands, Spain. Phytotaxa 219:118-132.

Walter, A. E., Turner, D. H., Kim, J., Lyttle, M. H., Müller, P., Mathews, D. H. \& Zuker, M. 1994. Coaxial stacking of helixes enhances binding of oligoribonucleotides and improves predictions of RNA folding. Proc. Natl. Acad. Sci. U. S. A. 91:9218-9222.

Warén, H. 1920. Reinkulturen von Flechtengonidien. Öfvers. Finska Vet.-Soc. Förh. 61A:1-79.

White, T. J., Bruns, T., Lee, S. \& Taylor, J. 1990. Amplification and direct sequencing of fungal ribosomal RNA genes for phylogenetics. In Innis, M. A., Gelfand, D. H., Sninsky, J. J. \& White, T. J. (Eds.) PCR Protocols: A Guide to Methods and Applications. Academic Press, San Diego, California, pp. 315-322.

Zuker, M. 2003. Mfold web server for nucleic acid folding and hybridization prediction. Nucleic Acids Res. 31:3406-3415. 